„Analecta Cracoviensia” 50 (2018), s. 193-212

DOI: http://dx.doi.org/10.15633/acr.3289

Marcin Rzepka

Uniwersytet Papieski Jana Pawła II w Krakowie

\title{
Działalność sióstr z anglikańskiego zgromadzenia Sisters of Bethany w Persji w latach 1890-1898 w kontekście relacji między Kościołem Anglii a Asyryjskim Kościołem Wschodu
}

Pod koniec Xıx wieku po trwających niemalże stulecie intensywnych kontaktach z misjonarzami z Europy oraz Ameryki Północnej poziom życia chrześcijan należących do Asyryjskiego Kościoła Wschodu, zamieszkujących tereny północno-zachodniej Persji, w porównaniu z ludnością muzułmańską znacznie się poprawił ${ }^{2}$ O wysokim rozwoju społecznym świadczyła rozbudowana sieć szkół, działające drukarnie oraz szpitale. Szkoły zakładane

\footnotetext{
Kwerendy w archiwach w Londynie (The National Archives, Lambet Palace Library) były możliwe dzięki stypendium Fundacji z Brzezia Lanckorońskich w 2013 roku. W 2015 roku pobyt w Portsmouth oraz kwerendy w archiwum zgromadzenia Society of the Sisters of Bethany stanowily część badań prowadzonych w ramach projektu finansowanego przez Narodowe Centrum Nauki na podstawie decyzji DEC-2012/05/E/Hs2/03779.

${ }^{2}$ Oficjalna nazwa Kościoła brzmi: Święty Apostolski Katolicki Asyryjski Kościół Wschodu. Należy on do Kościołów tradycji wschodniosyryjskiej. Wyjaśnienia wymaga używane w tekście określenie Asyryjczycy (w wąskim znaczeniu na określenie wyznawców Asyryjskiego Kościoła Wschodu). Nazwa ta pojawia się w tekstach misyjnych w drugiej połowie XIX wieku i zostaje upowszechniona właśnie przez anglikanów. W tym czasie nie używają jej jednak chrześcijanie tradycji wschodniosyryjskiej (por. I. Bird, Journey in Persia and Kurdistan Including a Summer in the Upper Karun Region and a Visit to the Nestorian Rayahs, vol. 2, London 1891, s. 237), na określenie siebie stosują inne terminy, zdecydowanie oponując przed używaniem wobec nich nazwy nestorianie (Nestorians); posługują się natomiast określeniami: chaldejczycy (Chaldeans), syryjczycy (Syrians), nazarejczycy (Nazareans). Por. J. Perkins, A Residence of Eight Years in Persia, Among the Nestorian Christians: with Notices of the Muhammedans, Andover-New York 1843,
} 
przez misjonarzy - pierwsza powstała w Urmii w 1835 roku z inicjatywy amerykańskiego misjonarza Justina Perkinsa - wpływały na większą mobilność chrześcijan, którzy kontynuując naukę poza granicami Persji, śmielej wyrażali aspiracje polityczne i narodowościowe. $\mathrm{W}$ istocie aktywność misyjna protestantów, a także Kościoła rzymskokatolickiego i Cerkwi rosyjskiej oraz wsparcie polityczne płynące z Wielkiej Brytanii, Francji, Stanów Zjednoczonych, Rosji przekładały się na podziały konfesyjne wśród Asyryjczyków, którzy negując tradycyjne formy autorytetu, dążyli do reformowania struktur kościelnych i społecznych. Istotne wydają się przy tym procesy kształtowania świadomości narodowej i postępujące wraz z nimi tendencje modernizacyjne ${ }^{3}$, które faktycznie wpłynęły na wykształcenie się instytucji świeckich, osłabiając tym samym dawne autorytety religijne.

Szczególną rolę w historii Asyryjskiego Kościoła Wschodu w drugiej połowie XIX wieku odegrały kontakty z Kościołem Anglii. Zbliżenie między Kościołami możliwe było dzięki powołaniu przez arcybiskupa Canterbury Edwarda W. Bensona specjalnej misji - The Archbishop of Canterbury's Mission to the Assyrian Christians. Jej powstanie wynikało bezpośrednio ze zmian, jakich doświadczali Asyryjczycy oraz intensyfikacji działań misyjnych podejmowanych wśród tej grupy w drugiej połowie XIX wieku. Stanowiło też wyraz zainteresowań Brytyjczyków regionem, w którym mieszkali chrześcijanie na obszarze pomiędzy Turcją osmańską a Persją. Relacje między Kościołem Anglii a Asyryjskim Kościołem Wschodu - obszernie przedstawione w fundamentalnej pracy Jamesa F. Coakleya, The Church of the East and the Church of England ${ }^{4}$ - skłaniają do refleksji nad zmianami społecznymi zachodzącymi w społeczeństwie brytyjskim okresu wiktoriańskiego oraz wśród chrześcijan tradycji wschodniosyryjskiej. Niniejszy artykuł, przedstawiając działalność anglikańskich sióstr należących do Society of the Sisters of Bethany [dalej: ssB] w Persji, w kontekście misji arcybiskupa Canterbury skupia się głównie na inicjatywach o charakterze edukacyjnym. Historia misji to jednak nie tylko przegląd działań misyjnych czy organizacyjnych, lecz także refleksja nad sposobami nabywania wiedzy o społecznościach, wśród których misje

s. 175; C. Baumer, The Church of the East. An illustrated History of Assyrian Christianity, London 2016, s. 7-8.

Doskonałą analizę przynosi praca: A. H. Becker, Revival and Awakening. American Evangelical Missionaries in Iran and the Origin of Assyrian Nationalism, Chicago-London 2015.

4 J. F. Coakley, The Church of the East and the Church of England: A History of the Archbishop of Canterbury's Assyrian Mission, Oxford 1992. 
były prowadzone. Ten aspekt jest dobrze widoczny w pracy sióstr. Istotnie bowiem misja do Asyryjczyków przyczyniła się do upowszechnienia wiedzy o Asyryjskimi Kościele Wschodu. Z takim zamiarem wydawano kwartalnik zatytułowany „Archbishop’s Mission to the Assyrian Christians. Quarterly Paper”. Na jego łamach ukazywały się artykuły poświęcone pracy misyjnej, informujące darczyńców i sympatyków misji o potrzebach związanych z dalszą działalnością. Stanowi on zatem doskonałe źródło do badań. W piśmie ukazywały się również listy sióstr, które - ze względu na charakter prowadzonej przez nie działalności - stanowią cenny materiał do poznania życia codziennego członków Asyryjskiego Kościoła Wschodu, zwłaszcza kobiet. Wybór listów zamieszczono w publikacji o tytule eksponującym kontakty z Kurdami: Christians and Kurds 5 , która ukazała się 1913 roku. Podstawowym źródłem pozostają jednak materiały $z$ archiwum zakonnego Society of the Sisters of Bethany [dalej: ssBA], znajdujące się obecnie w Portsmouth w Wielkiej Brytanii, na które składają się głównie listy sióstr. Część z nich, w tym zdecydowana większość napisanych przez s. Katharine Mildred do matki przełożonej, została jednak zniszczona ${ }^{6}$.

\section{Kościół Anglii i Asyryjski Kościół Wschodu w XIx wieku: ustanowienie relacji}

Misja arcybiskupa - w przeciwieństwie do działających już wśród Asyryjczyków misji protestanckich i katolickich - nie miała doprowadzić do unii, lecz wesprzeć istniejące struktury kościelne poprzez edukację duchownych, rozwój szkolnictwa religijnego i świeckiego wśród młodych oraz druk wczesnych liturgii Kościoła ${ }^{7}$. Pierwsze formalne działania na rzecz powstania misji podjął arcybiskup Archibald Tait (1862-1882). Przybrała ona właściwy kształt za czasów kolejnego arcybiskupa Edwarda Bensona (1883-1896). W tym czasie doszło do prób redefiniowania tradycji anglikańskiej poprzez położenie większego nacisku na współpracę z innymi Kościołami, zwłaszcza wschodnimi. Benson aktywnie wsparł ideę restauracji anglikańskiego biskupstwa w Jerozolimie oraz przyczynił się do ożywienia dialogu z Kościołem prawosławnym. W obrębie Kościoła Anglii frakcja „kościoła wysokiego” (high

\footnotetext{
F. N. Heazell, J. P. Margoliouth, Kurds and Christians, London 1913.

6 Pisze o tym szerzej J. F. Coakley, The Church of the East..., dz. cyt., s. 208. Obecnie siostry uporządkowały i opisały posiadane przez siebie zbiory, zajęły się również edycją rękopisów.

7 Zob. I. Bird, Journey in Persia..., dz. cyt., s. 230.
} 
Church) akcentująca katolickie dziedzictwo Kościoła, a także ruch oksfordzki przyczyniły się do powstania anglikańskich zgromadzeń zakonnych - pierwszych od czasów reformacji ${ }^{8}$.

Działalność sióstr ssB wśród kobiet należących do Asyryjskiego Kościoła Wschodu w Persji związana była z misją arcybiskupa Canterbury do Asyryjczyków, powołanej w celu wsparcia Kościoła, a przy tym jego reformowania i odnowienia. Reformowanie rozumiano przede wszystkim jako podniesienie poziomu edukacji, w pierwszej kolejności wśród asyryjskiego kleru, a następnie zwykłych członków Kościoła, w tym kobiet.

Zainteresowanie Asyryjskim Kościołem Wschodu wśród pracowników różnych agend Kościoła Anglii w xIx wieku było wprost proporcjonalne do informacji, jakie docierały w tym czasie do Wielkiej Brytanii na temat wiernych tego Kościoła. W dużym stopniu wzrost zainteresowania chrześcijanami rozproszonymi po wschodnich wilajetach Turcji osmańskiej i północno-zachodniej Persji warunkowała działalności misyjna prowadzona przez Amerykanów w Urmii wśród asyryjskich chrześcijan oraz ekspedycje naukowe podejmowane przez Brytyjczyków. Amerykanie upowszechniali uproszczony i odbiegający od rzeczywistości obraz reprezentantów asyryjskiej społeczności, określając ich jako „protestantów Wschodu”. Zaś ekspedycje brytyjskie, zwłaszcza wyprawa $\mathrm{z} 1835$ roku pod auspicjami Royal Geographical Society ${ }^{10}$ do imperium osmańskiego, pozwoliły na bezpośredni kontakt z przedstawicielami Kościoła. W tym roku jeden z tłumaczy zatrudniony przez Brytyjczyków - Isa Rassam ${ }^{11}$ sugerował większe zbliżenie z Kościołem Anglii' ${ }^{12}$. W 1837 roku zainteresowanie współpracą wyrażał biskup Londynu Charles J. Bloomfiels oraz William Howley, który przewodził w tym czasie The Society for Promoting Christian Knowledge [dalej: SPCK]. W 1838 roku William Ainsworth oraz Rassam otrzymali z SPCK polecenie przygotowania raportu dotyczącego kondycji chrześcijan

8 Szerzej o zgromadzeniach żeńskich: S. Mumm, Stolen Daughters, Virgin Mothers: Anglican Sisterhoods in Victorian Britain, London 1999. Około 1900 roku w Anglii było 3-4 tys. sióstr zakonnych, które skupione w ok. 6o zgromadzeniach tworzyły najbardziej zwartą grupę kobiet w wiktoriańskiej Anglii. Zob. S. Mumm, Stolen Daughters..., dz. cyt., s. 3-4.

9 Zob. J. Perkins, A Residence of Eight Years in Persia..., dz. cyt., s. 20. Dość istotne wydają się również raporty Dwighta i Smitha: H. G. Dwight, E. Smith, Researches in Armenia including a journey through Asia Minor and into Georgia and Persia, vol. 1-2, Boston 1833.

${ }^{10}$ J. S. Guest, The Euphrates Expedition, London 1992.

${ }^{11}$ Znany później jako Christian Antun Rassam, ur. w Mosulu w 1808 roku w arystokratycznej chaldejskiej rodzinie.

${ }_{12}$ Zob. J. F. Coakley, The Church of the East..., dz. cyt., s. 22. 
w Kurdystanie. Nieco później dołączył do nich duchowny anglikański George Percy Badger ${ }^{13}$, który w 1842 roku osobiście spotkał się z patriarchą Mar Szimunem xvir Abrahamem. Efektem tych działań była przygotowana przez Badgera obszerna praca dotycząca „nestorian”, jak wówczas określano członków tej społeczności ${ }^{14}$.

Kontakty z misjonarzami miały daleko idące konsekwencje dla Asyryjskiego Kościoła Wschodu. Pomijając zasadność określenia Asyryjczyków „protestantami Wschodu", należy podkreślić, że wczesne kontakty z Amerykanami doprowadziły do przemian społecznych inicjowanych poprzez edukację. Nowoczesność oferowana przez instytucje misyjne zasadzała się w pierwszej kolejności na wykorzystaniu druku stymulującego zarówno kodyfikację języka neoaramejskiego używanego dotychczas jako medium w komunikacji ustnej ${ }^{15}$, jak również większe otwarcie i mobilność całej grupy. Działalność misjonarzy amerykańskich oraz francuskich w Persji śledzili bacznie dyplomaci brytyjscy. Brytyjski konsul w Tebrizie Keith Abbott (pracował w Persji w latach 1854-1868) informował o działalności lazarystów w Chosrowie i konfliktach, w jakie wdali się z patriarchą Asyryjskiego Kościoła Wschodu ${ }^{16}$, wyrażał przy tym obawy przed wpływami Kościoła rzymskokatolickiego w regionie. Charles Murray, przedstawiciel królowej brytyjskiej na dworze szacha Persji, w czasie swojej wizyty w Urmii w 1856 roku spotkał się z pracownikami misji amerykańskiej, którzy pozostawali wówczas pod opieką konsularną Wielkiej Brytanii. Amerykanie zdawali się monopolizować pracę wśród Asyryjczyków. Murray zwracał na to uwagę, przedstawiając szkic działań misyjnych wraz $\mathrm{z}$ uwzględnieniem projektów związanych z rozwojem szkolnictwa w regionie. Edukacja obejmowała naukę czytania, pisania, arytmetyki, geografii, zaś językiem nauczania był neoaramejski, na który też została przetłumaczona Biblia. Opowieści biblijne stanowiły w istocie podstawę prowadzonych lekcji. Starsze dzieci po opanowaniu materiału i po ukończeniu szkoły powracały do swoich wsi i wiosek, by tam uczyć młodszych. Tym sposobem w stosunkowo krótkim czasie upowszechniała się co najmniej elementarna znajomość pisania i czytania. Murray porównywał osiągnięcia Amerykanów z misją katolicką,

${ }^{13}$ Zob. The National Archives [dalej: TNA], FO 78/2698, Memorandum of Instructions to the Rev. G.P. Badger on his Departure to Kurdistan.

${ }_{14}$ Zob. G. P. Badger, The Nestorians and their Rituals, vol. 1-2, London 1852.

${ }_{15}$ Zob. H. L. Murre-van den Berg, From a Spoken to a Written Language. The Introduction and Development of Literary Urmia Aramaic in the Nineteenth Century, Leiden 1999.

${ }_{16}$ Zob. TNA, FO 78/2700, List Abbotta do Foreign Office, Tebriz, 9.09.1854. 
która - jego zdaniem - nie mogła pochwalić się takimi sukcesami. Relację zakończył jednak stwierdzeniem, że „Nestorianie w Persji są najbiedniejszą i najbardziej prześladowaną grupą społeczną"17. Wyłania się z niej obraz podziałów wśród Asyryjczyków wywołanych pracą misjonarzy z Europy oraz Ameryki, a przy tym również wyobrażenie „nestorian” jako jedynej grupy pozbawionej protekcji politycznej. Zatem przekonanie - wyrażane przez brytyjskich dyplomatów - o konieczności podjęcia działań na rzecz tej grupy w sytuacji rywalizacji misyjnej między protestantami i katolikami oraz w odniesieniu do reform podejmowanych w Persji i Turcji osmańskiej wpłynęło bezpośrednio na projekty misji arcybiskupa Canterbury, kształtując również wyobrażenia anglikanów dotyczące chrześcijan wschodnich.

Nie sposób jednak pominąć roli patriarchy Asyryjskiego Kościoła Wschodu. Jego funkcja nie ograniczała się jedynie do spraw związanych z religią. Był on absolutnym przywódcą politycznym i odpowiadał za kontakty z władcami, monarchami, reprezentantami innych Kościołów. W drugiej połowie xIx wieku patriarcha Asyryjskiego Kościoła Wschodu Mar Szimun Xvıı Ruben wykazywał znaczną aktywność w poszukiwaniu europejskich sojuszników. W latach 6o. patriarcha wysyłał petycje do cara Rosji1 ${ }^{18}$ oraz królowej Wiktorii. W 1868 roku, prawdopodobnie bez wiedzy ówczesnego patriarchy Mar Szimuna XVIII Rubena (1861-1903) rezydującego w Koczanis (dziś: Konak), biskup Gawar (dziś: Yüksekova) wysłał notę do arcybiskupa Taita z prośbą o pomoc i ochronę ${ }^{19}$. Dowodzi ona tarć w obrębie Kościoła związanych z deklarowaną wcześniej przez patriarchę chęcią zbliżenia z Kościołem rzymskokatolickim ${ }^{20}$.

Na decyzję arcybiskupa Canterbury o ustanowieniu formalnych kontaktów z patriarchą Asyryjskiego Kościoła Wschodu wpłynęły niewątpliwie umiędzynarodowienie problemu chrześcijan z Turcji osmańskiej i Persji oraz raporty przygotowane przez brytyjskie Foreign Office dotyczące prześladowań sięgających czasów kurdyjskiego powstania z połowy wieku pod wodzą Bedyr-chana. W 1876 roku anglikański duchowny Edward L. Cutts z ramienia Kościoła Anglii nawiązał kontakty z patriarchą Mar Szimunem Xviı. Wraz z synem

${ }_{17}$ TNA, FO 78/2700, List Murraya do Foreign Office, Urmia, 3.04.1856. [Wszystkie cytaty, jeśli nie zaznaczono inaczej, podaję we własnym tłumaczeniu].

${ }_{18}$ Zob. J. F. Coakley, The Church of the East..., dz. cyt., s. 128.

19 Zob. D. Wimshurst, The martyred Church. A History of the Church of the East, London 2011, s. 375 .

${ }^{20}$ Zob. TNA, FO 78/2702, Memorandum Respecting the Persecution of the Nestorian Christians by the Turks, Persians and Khoodish Chiefs, December 1876, s. 31. 
Williamem oraz diakonem anglikańskim pochodzącym z Persji George’em Hormuzdem, który był jednym z kilku Asyryjczyków studiujących wówczas w Anglii, udał się w podróż do Koczanis, by tam spotkać się z patriarchą. W czasie drogi powrotnej Cutts przygotował raport zatytułowany The Assyrian Christians ${ }^{21}$, w którym przedstawił szacunkowy koszt postulowanej misji - 2000 funtów. Raport ten jest jednak istotny $z$ innego względu. Jego autor, przejeżdżając przez różne miejscowości wschodniej części Turcji omańskiej i północno-zachodniej Persji, między innymi przez Diarbakır, Koczanis, Urmię, Tebriz, zebrał dane statystyczne dotyczące ludności, scharakteryzował podziały wśród chrześcijan oraz określił ich stosunek do Kościoła Anglii. Przekonywał, że chrześcijanie: „są świadomi swojego zapóźnienia cywilizacyjnego, pragną zmian, uznając, że ulepszony i rozwinięty system edukacji jest pierwszym krokiem w rozwoju; $\mathrm{z}$ radością przyjęli ofertę pomocy skierowaną do nich przez arcybiskupa"22. Sprawa edukacji stała się zatem priorytetowa. Patriarcha sugerował konieczność nauczania dzieci języka klasycznego, traktując go jako gwarancję zachowania tradycji. Nacisk na naukę klasycznego języka stanowił w istocie krytykę metod edukacyjnych Amerykanów oraz działań zmierzających do monopolizowania przez nich szkolnictwa ${ }^{23}$. Tekst Cuttsa ukazuje przy tym delikatny problem relacji między misjami a polityką: „W tym kraju każdy Europejczyk o uznanej pozycji staje się nieformalnym wicekonsulem. Księża rzymskokatoliccy rozciągnęli francuską protekcję na swoich konwertytów. Amerykańscy misjonarze w Urmii działają na takich samych zasadach wobec swoich podopiecznych poprzez konsulów brytyjskich i ambasadora"24. Te słowa mają podobny wydźwięk, jak przywołane wcześniej opinie dyplomaty Murraya. Stosunek patriarchy do Kościoła Anglii wydaje się być wypadkową sytuacji społecznej i politycznej.

W 1881 roku arcybiskup Tait wysłał Rudolpha Wahla, duchownego anglikańskiego, który pracował wcześniej w London Jew’s Society w celu założenia szkoły w Koczanis. W 1884 roku Athelstan Riley udał się do Kurdystanu z podobną misją. Nie przyniosły one jednak trwałych rezultatów. Riley sugerował utworzenie dwóch stacji misyjnych, jednej w Koczanis (w Imperium Osmańskim)

${ }^{21}$ E. L. Cutts, The Assyrian Christians. Report of a Journey, undertaken by desire of His Grace the Archbishop of Canterbury and His Grace the Archbishop of York to the Christians in Koordistan and Oroomiah, London 1877.

${ }^{22}$ E. L. Cutts, The Assyrian Christians..., dz. cyt., s. 12.

${ }_{23}$ Zob. E. L. Cutts, Christians under the Crecsent in Asia, London 1878, s. 350.

${ }^{24}$ E. L. Cutts, The Assyrian Christians..., dz. cyt., s. 12. 
drugiej w Urmii, podkreślając znaczenie edukacji oraz publikacji książek ${ }^{25}$. W swoim raporcie informował o działalności misji katolickiej mającej swoją siedzibę w Chosrowie i o siedmiu pracujących w niej zakonnicach ze zgromadzenia Filles de la charité de Saint Vincent de Paul. Jest to istotne, gdyż w ten sposób Riley dowodził zasadności prowadzenia pracy wśród kobiet przez kobiety.

Rzeczywisty rozwój misji związany był jednak z działalnością dwóch duchownych anglikańskich: Arthura Johna Macleana oraz Williama Henry’ego Browne’a, którzy począwszy od 1885 roku stopniowo rozwijali sieć szkół na obszarach pomiędzy Koczanis a Urmią. Od roku 1887 redagowali oni krótkie sprawozdania z działalności noszące nazwę „Letters from Assyria” adresowane do wiernych Kościoła Anglii, sympatyków misji arcybiskupa oraz wszystkich zainteresowanych Asyryjskim Kościołem Wschodu. Pisane przez nich artykuły i raporty ukazują życie Asyryjczyków po obu stronach granicy osmańsko-perskiej, stanowią pierwszorzędne źródło do badań życia codziennego chrześcijan. W pierwszym opublikowanym liście z Urmii Maclean informował, że początkowy limit 20 uczniów w szkole średniej ze względu na duże zainteresowanie nie mógł być utrzymany ${ }^{26}$. Zwiększono go do 36 uczniów. Wydaje się, że w tym okresie kładziono duży nacisk na kształcenie, czy może raczej dokształcanie niższego kleru Kościoła oraz tych, którzy mogli później podjąć się nauczania. Przykładowo zajęcia dla księży obejmowały: klasyczny język syryjski, angielski oraz arytmetykę, zajęcia z egzegezy biblijnej, zajęcia poświęcone „wyznaniu wiary”, zajęcia z liturgii syryjskiej. Niektórzy uczyli się również języka perskiego lub osmańskiego. Chłopcy mieli w programie jedną godzinę lekcji teologii dziennie (zajęcia prowadził Browne oraz Maclean), geografię, arytmetykę, język klasyczny, angielski (opcjonalnie) ${ }^{27}$. Zakładane przez anglikanów szkoły musiały wpasować się w istniejący już i rozwijany przez misjonarzy z US A oraz Francji system edukacji. Nie dziwią zatem pojawiające się w raportach odwołania i porównania do szkół prowadzonych przez Amerykanów oraz księży rzymskokatolickich. Browne sugerował, że „ci, którzy przeszli przez ręce Francuzów, są milsi, o łagodnych manierach, uważni i pełni szacunku. Nie sądzę - powiada dalej Browne - że ci, którzy pozostawali pod wpływem Amerykanów, byli doskonalsi, wręcz przeciwnie, a dowodzi tego

${ }^{25}$ Zob. Lambet Palace Library [dalej: LPL]. Assyrian Mission Papers G 3200 3, A. Riley, Narrative of a visit to the Assyrian Christians in Kurdistan, undertaken at the request of the Archbishop of Canterbury in the autumn of 1884 [1888].

${ }^{26}$ Zob. „Letters from Assyria” 1887 no. 1, s. 1.

27 Zob. „Letters from Assyria” 1887 no. 1, s. 3. 
ich stosunek do innych. Nie piją, a może raczej ich pasterze nie piją zbyt wiele wina, śmiem jednak twierdzić, że mogliby być lepsi i w innych sprawach"28. Ta, niemalże anegdotyczna informacja, ma jednak duże znaczenie dla zrozumienia charakteru prowadzonych misji oraz sposobów nauczania. W istocie szkoły prowadzone przez Amerykanów charakteryzowały się znaczną uniformizacją, narzucały uczniom sposób ubierania się i zachowania, dokonując swoistej fizycznej przemiany uczących się dzieci. Misja anglikańska starała się uniknąć wszelkich form „westernizacji”. W kontekście edukacji nie bez znaczenia są informacje dotyczące kształcenia kobiet. Prezbiteriańska misja jako pierwsza otworzyła szkołę dla dziewcząt, kierowaną przez Fidelię Fiske (1816-1864). Podobnie misja katolicka po przyjeździe sióstr ze zgromadzenia Filles de la charité de Saint Vincent de Paul w 1856 roku rozpoczęła kształcenie dziewcząt ${ }^{29}$. W przypadku Kościoła Anglii zainteresowanie losem kobiet z Asyryjskiego Kościoła Wschodu wzbudzały zarówno raporty reprezentantów arcybiskupa $\mathrm{w}$ regionie, jak i literatura popularna ${ }^{30}$. Wspomniany wcześniej Cutts opublikował książkę dla dzieci zatytułowaną Amina: A Tale of the Nestorians $^{31}$. Tytułowa postać - dziewczyna imieniem Amina zostaje uprowadzona przez Kurdów; społeczność asyryjska, nie mogąc uzyskać pomocy od perskich notabli, decyduje się odbić uprowadzoną pod wodzą przebywającego we wsi Anglika. Książka w sposób prosty, lecz sugestywny ukazuje relacje między chrześcijanami a muzułmanami - Kurdami oraz konieczność wsparcia społeczności Asyryjczyków z zewnątrz, w tym przypadku z Wielkiej Brytanii. Wraz z rozwojem misji kierowanej przez Browne’a i Macleana kształtowała się również idea szkół dla dziewcząt i kobiet.

\section{Sisters of Bethany: organizacja i charakter pracy w Persji}

Działalność sióstr otwiera dyskusję nad rolą kobiet na misjach, ukazując przemiany, jakie zachodziły w działalności misyjnej w XIX wieku oraz początki rodzącego się kobiecego ruchu misyjnego w protestantyzmie ${ }^{32}$. W konsekwencji

28 „Letters from Assyria” 1887 no 2.

${ }^{29} \mathrm{~W} 1856$ roku siostry zostały sprowadzone do Persji z Konstantynopola. Zob. R. Waterfield, Christians in Persia. Assyrians, Armenians, Roman Catholics and Protestants, London 1973, s. 81-82.

${ }^{30}$ Zob. J. F. Coakley, Assyrian Christians in English Fiction, 1849-1967, „Journal of Assyrian Academic Studies" 23 (2009) no. 2, s. 18-25.

${ }^{31}$ E. L. Cutts, Amina: A Tale of the Nestorians, London [1890].

${ }^{32}$ Zob. G. E. Francis-Dehqani, Religious Feminism in an Age of Empire. CMs Women Missionaries in Iran 1869-1934, Bristol 2000. 
kobiety wyjeżdżały na misje już nie jako żony misjonarzy, lecz jako misjonarki. Sytuacja taka jest stosunkowo dobrze widoczna w przypadku misji amerykańskich oraz brytyjskich firmowanych przez Church Missionary Society. Jednak w odniesieniu do misji arcybiskupa Canterbury do Asyryjczyków inspiracją dla pracy kobiet na misjach były rozwiązania katolickie, bezpośrednio zaś praca francuskich sióstr w Chosrowie. Rzecznikiem wysłania anglikańskich zakonnic był Riley, który po powrocie z podróży do Persji przekonywał arcybiskupa Bensona o konieczności podjęcia tego typu działań. Riley skontaktował się z matką przełożoną zgromadzenia Community of All Saints Sisters of the Poor, pytając o możliwość wysłania sióstr na misje. Ta jednak, odmawiając, zasugerowała niewielkie zgromadzenie mające wówczas siedzibę na Lloyd Square w Londynie - Society of the Sisters of Bethany. Riley wiosną 1889 rozpoczął rozmowy z Etheldredą Anną, która zanim założyła własne zgromadzenie w 1866 roku, odbyła nowicjat w u sióstr „All Saints”. Pozytywnie odniosła się do projektu pracy w Persji. Jej zapał studził nieco Richard Meux Benson (1824-1915), anglikański duchowny i założyciel męskiego zgromadzenia Society of Saint John the Evangelist. Przekonywał on, że siostry powinny pracować w miejscach, gdzie jest więcej anglikanów, a potrzeby są znacznie większe: w Stanach Zjednoczonych, Afryce czy Indiach. Wątpił też w możliwość prowadzenia misji bez doskonałego opanowania języka ${ }^{33}$. Mimo to w 1889 roku wytypowano cztery siostry do pracy w Urmii wśród Asyryjczyków, wśród nich były: s. Katherine Mildred (Marchall), która została przełożoną misji, s. Ellen Joanna (Bruton), s. Gabrielle Marie i s. Martha - „świecka siostra” (zob. tab. 1). Pod koniec 1889 roku rozpoczęto przygotowania do wyjazdu, zaś na początku 1890 roku Riley, przebywając w Petersburgu, otrzymał od Świętego Synodu pozwolenie dla sióstr na przejazd przez terytorium Rosji. Otrzymawszy szereg instrukcji od Macleana za pośrednictwem matki przełożonej ${ }^{34} 17$ kwietnia 1890 roku cztery siostry wraz z kapelanem ks. Arthurem Jarvisem wyruszyły do Urmii. Jednak już kilka miesięcy przed wyjazdem w ramach przygotowań zaczęły uczyć się języka neoaramejskiego ${ }^{35}$. W tym też czasie w samej Urmii Maclean poszukiwał lokum dla sióstr w pobliżu kościoła Mart Mariam. 16 maja 1890 roku siostry dotarły do Urmii, początkowo zamieszkały jednak oddalonej o około osiem kilometrów od Urmii niewielkiej miejscowości Seir.

33 Zob. ssBA, List Bensona do Etheldredy Anny, 14.05.1889.

${ }^{34}$ Wskazówki miały bardzo praktyczny charakter i dotyczyły podróży, bezpieczeństwa.

35 Korzystały między innymi z gramatyki Stodarda: ssbA, List Macleana do Etheldredy Anny, 12.09.1889. 
Misja rozpoczęta w 1890 roku zakończyła się wraz z wyjazdem ostatniej z sióstr w 1898 roku. W chwili rozpoczęcia niewątpliwie zamierzano rozwijać ją stopniowo ${ }^{36}$. Jednak z czasem okazało się, że panujący klimat, warunki bytowe oraz problemy zdrowotne znacznie utrudniały jej funkcjonowanie. Rok po przyjeździe zmarł kapelan sióstr ks. Jervis. W roku 1894 zmarła s. Katherine. W roku 1893 roku misję opuściła s. Gabrielle Marie. W tym też roku misja została wsparta przez dwie nowe siostry (zob. tab. 1). Trudności w pracy wynikały również z sytuacji politycznej. W 1895 roku dotarły do Urmii informacje o masakrach chrześcijan w rejonie jeziora Wan, a w samym mieście wzrastało zagrożenie ze strony koczowniczych plemion kurdyjskich ${ }^{37}$. W 1895 roku misję opuściła s. Francis, natomiast przyjechały dwie kolejne siostry - Margaret Hilda i Elizabeth Grace. Niewątpliwie również zwiększające się wpływy Rosjan w regionie - w 1898 roku została utworzona rosyjska prawosławna misja w Urmii - potęgowały trudność w prowadzeniu działań misyjnych. W maju 1898 roku s. Pauline pisała do matki przełożonej: „Słyszałyśmy, że Kościół rosyjski wydaje się myśleć o poważnej pracy tutaj, może byłoby więc rzeczą słuszną, odwołać nas teraz" ${ }^{38}$. Po miesiącu s. Pauline i s. Margaret Hilda zakończyły pracę, kończąc tym samym krótki, ośmioletni okres działalności sióstr w Persji.

Tabela 1. Wykaz sióstr pracujących w Persji wraz z kapelanami misji

\begin{tabular}{|c|c|c|c|}
\hline & doświadczenie, charakter pracy & $\begin{array}{c}\text { wyjazd } \\
\text { do Persji }\end{array}$ & $\begin{array}{l}\text { powrót/ } \\
\text { zakończenie } \\
\text { pracy w Persji }\end{array}$ \\
\hline $\begin{array}{l}\text { s. Katharine } \\
\text { Mildred }\end{array}$ & $\begin{array}{l}\text { przełożona misji; } \\
\text { w chwili wyjazdu miała } 40 \text { lat, osiem } \\
\text { lat po ślubach; } \\
\text { ukończyła sześciomiesięczny kurs } \\
\text { medyczny w University College } \\
\text { Hospital; } \\
\text { uczyła się hebrajskiego, miała dobre } \\
\text { przygotowanie językowe; } \\
\text { zajmowała się nauczaniem, } \\
\text { pielęgniarstwem }\end{array}$ & 17.04 .1890 & $\begin{array}{l}\text { zmarła w Urmii } \\
15.11 .1894\end{array}$ \\
\hline
\end{tabular}

${ }^{36}$ Świadczą o tym list sióstr, Ellen Joanna już a październiku 1890 roku pytała matkę przełożoną o siostry, które zaczęły się uczyć neoaramejskiego. Zob. ssBA, List s. Ellen Joanny do matki przełożonej, 11.10.189o.

37 W czerwcu 1896 roku został zamordowany bp Mar Gauriel.

${ }_{38}$ ssBA, List s. Anne Pauline do matki przełożonej, 8.05.1898. 


\begin{tabular}{|c|c|c|c|}
\hline & doświadczenie, charakter pracy & $\begin{array}{l}\text { wyjazd } \\
\text { do Persji }\end{array}$ & $\begin{array}{l}\text { powrót/ } \\
\text { zakończenie } \\
\text { pracy w Persji }\end{array}$ \\
\hline s. Ellen Joanna & $\begin{array}{l}\text { asystująca s. Mildred, a po jej śmierci - } \\
\text { przełożona misji; } \\
\text { w chwili wyjazdu miała } 38 \text { lat, profesja } \\
\text { zakonna w } 1890 ; \\
\text { zajmowała się nauczaniem, } \\
\text { pielęgniarstwem, ogrodnictwem }\end{array}$ & 17.04 .1890 & maj 1896 \\
\hline s. Gabrielle Marie & $\begin{array}{l}\text { w chwili wyjazdu miała } 38 \text { lat, osiem } \\
\text { lat po ślubach }\end{array}$ & 17.04 .1890 & 13.05 .1893 \\
\hline s. Martha & $\begin{array}{l}\text { w chwili wyjazdu miała } 25 \text { lat, profesja } \\
\text { zakonna w 1888; } \\
\text { nauczanie, pomoc i organizacja pracy } \\
\text { misyjnej }\end{array}$ & 17.04 .1890 & czerwiec 1897 \\
\hline s. Francis & na misjach zajmowała się nauczaniem & 28.08 .1893 & kwiecień 1895 \\
\hline s. Anne Pauline & na misjach zajmowała się nauczaniem & 28.08 .1893 & 12.06. 1898 \\
\hline s. Margaret Hilda & $\begin{array}{l}\text { od maja } 1896 \text { przełożona misji; } \\
\text { zajmowała się nauczaniem, praca } \\
\text { wśród kobiet na wsiach }\end{array}$ & 30.10 .1895 & 12.06. 1898 \\
\hline s. Elizabeth Grace & na misjach zajmowała się nauczaniem & 30.10 .1895 & czerwiec 1897 \\
\hline ks. Arthur Jervis & kapelan sióstr & 17.04 .1890 & $\begin{array}{l}\text { zmarł w Urmii } \\
3.10 .1891\end{array}$ \\
\hline ks. David Jenks & kapelan sióstr & sierpień 1892 & 1899 \\
\hline
\end{tabular}

Źródło: ssBA, The Persian Adventure 1890-1898; A. S. Jervis, Diary in Persia with Memoir, Worthing 1893 .

Po przyjeździe do Urmii siostry rozpoczęły pod kierunkiem Macleana naukę języka neoramejskiego, głównie gramatyki, uczestniczyły również w nabożeństwach prowadzonych w języku klasycznym. W kontaktach z miejscową ludnością korzystały początkowo z pomocy tłumacza. Jednak ich głównym zajęciem miała być praca wśród kobiet i dziewcząt. Zanim przyjechały, Gulnaz Neesan - żona duchownego Asyryjczyka Yaroo Michaela Neesana - rozpoczęła przygotowania do otwarcia szkoły średniej dla dziewcząt. 
W 1890 roku w szkołach prowadzonych przez anglikanów uczyło się już 1245 chłopców oraz 225 dziewczynek ${ }^{39}$. Liczba uczniów zwiększała się w kolejnych latach. W raporcie z 1891 roku czytamy, że na prowadzone przez siostry lekcje uczęszczało 40 uczniów ${ }^{40}$. Prowadzenie zajęć wymagało korzystania z pomocy naukowych oraz podręczników, siostry otrzymywały zatem z Londynu mapy, albumy oraz pisma ilustrowane, które wykorzystywały w czasie lekcji. Otrzymywały również książki dla dzieci ${ }^{41}$. Dość istotnym elementem nauczania były zajęcia praktyczne, szczególnie nauka szycia. Siostra Katharine, mając przygotowanie pielęgniarskie i medyczne, zajmowała się pomocą chorym. Elementy pielęgniarstwa, położnictwa stanowiły również część edukacji.

Nacisk na praktyczny wymiar nauki wynikał z określenia celu edukacji. Browne i Maclean, inicjując działania edukacyjne, byli przekonani o tym, że niewielu wyedukowanych chłopców może zostać duchownymi, nauczycielami lub znaleźć zatrudnienie w drukarni czy innych instytucjach należących do misji. Odpierając jednak zarzuty krytyków, którzy podważali celowość i zasadność prowadzenia szkół w społeczności konserwatywnej i tradycyjnej, misjonarze przekonywali, że edukacja może zmienić percepcję i postawy społeczne, zaś możliwość ożywienia społeczności Asyryjczyków widzieli w rozwoju handlu, warunkującego ich zdaniem większą mobilność ${ }^{42}$. Edukacja dziewczynek napotykała dodatkowo sprzeciw pewnej części społeczeństwa, kierującej się uprzedzeniami, stereotypami oraz - jak twierdzili misjonarze - będącej pod wpływem muzułmanów w podejściu do kobiet ${ }^{43}$. Kim zatem były dziewczynki uczestniczące w zajęciach prowadzonych przez misjonarzy? Zważywszy na bardzo silne podziały w społeczeństwie chrześcijan wschodnich, przy tym również rozbudowaną strukturę plemienną, wydaje się, że początkowo do szkół

39 Zob. „Archbishop's Mission to the Assyrian Christians Quarterly Paper” no. 1, 1.10.189o, s. 1-2.

${ }^{40}$ Zob. „Archbishop's Mission to the Assyrian Christians Quarterly Paper” no. 5, 1.10.1891, s. 55.

${ }^{41}$ W listach siostry podkreślają jednak ich znikomą przydatność, zważywszy na to, że odnoszą się do angielskich realiów. Por. „Archbishop’s Mission to the Assyrian Christians Quarterly Paper” no. 7, 1.04.1892, s. 32 .

${ }^{42}$ Zob. W. H. Browne, A. J. Maclean, The Catholicos of the East and His People being the Impression of Five Years' Work in the "Archbishop of Canterbury's Assyrian Mission”. An Account of the Religious and Secular Life and Opinions of the Eastern Syrian Christians of Kurdistan and Northern Persia, London 1892, s. 178-179.

43 Do problemów, z jakimi musiały zmierzyć się siostry, należały: niski wiek zawierania małżeństw przez dziewczynki (12 lat), ciąże w bardzo młodym wieku. Por. I. Bird, Journey in Persia..., dz. cyt., s. 232. 
uczęszczały głównie córki malików, przywódców plemiennych, rodowych lub asyryjskich notabli. Z czasem zaczęto jednak przyjmować również dziewczynki z biedniejszych rodzin, zapewniając im wyżywienie.

Siostra Katherine, jako przełożona sióstr i posiadająca największe doświadczenie językowe, prowadziła zajęcia przez trzy godziny dziennie. Dodatkowo wraz z jedną z sióstr, głównie Ellen Joanną, wyjeżdżała dwa razy w tygodniu do wiosek znajdujących się w okolicy miasta Urmia, by spotykać się z kobietami i rozmawiać z nimi. Rozmowy dotyczyły zarówno zagadnień religijnych, jak i społecznych czy kulturowych. Zazwyczaj kobiety zbierały się w domu miejscowego księdza ${ }^{44}$. Spotkania, zważywszy na informacje przekazywane przez s. Katherine w listach o kobietach nieznających nawet Modlitwy Pańskiej, miały symboliczne znaczenie, włączały kobiety w społeczność Kościoła.

Bardzo silnie akcentowano konieczność zachowania lokalnych zwyczajów oraz strojów, czyli tych elementów, których pozbawiała Asyryjczyków szkoła prowadzona przez Amerykanów. „Siostry nauczając te dziewczynki starannie unikały tego, co mogłoby prowadzić do ich wynarodowienia (org. 'to denationalize them'). [Dziewczynki] Ubierały się w syryjskie stroje, jadły syryjskie potrawy, a ich zachowania odpowiadały wzorcom syryjskim, były one wychowywane, aby pełnić rolę syryjskich żon i matek. Wszystko to było bardzo istotne, bowiem misja, która wynaradawia, pozostaje chorobliwą egzotyką między ludźmi" 45 . Podejście do edukacji odpowiadało zatem modelowi prowadzenia i rozumienia misji, wywołując przy tym dyskusję nad tym, co lokalne i uniwersalne w pracy misyjnej. Działalność sióstr w Persji - jako części misji anglikańskiej - była pod tym względem szczególna. Opierała się bowiem na założeniu, że zachowanie tożsamości wiernych, wyrażanej właśnie w strojach, zwyczajach, zabawach, jedzeniu jest absolutnie konieczne. Doskonałym przykładem takiego podejścia może być postawa Browne’a, który „fizycznie” przemienił się w jednego z Asyryjczyków. Wspomina o tym Isabelle Bird, która po spotkaniu w 1890 roku w Koczanis z patriarchą i Brownem, stwierdziła, że misjonarz, mieszkając wśród Asyryjczyków, w pełni upodobnił się do nich ${ }^{46}$. Wygląd, a zatem jego broda, ubiór oraz styl życia - bardzo różny od standardów wiktoriańskiej Anglii - zdziwił również s. Anne Pauline, która

44 Zob. Letter form Sister Katherine Mildred to the Archbishop, „Archbishop's Mission to the Assyrian Christians Quarterly Paper” no. 3, 1.04.1891, s. 17.

45 „Archbishop's Mission to the Assyrian Christians Quarterly Paper” no. 8, 1.07.1892, s. 47.

${ }_{46}$ Zob. I. Bird, Journey in Persia..., dz. cyt., s. 285. O wizycie Bird wspomina jedna z sióstr: SSBA, List s. Ellen Joanny do matki przełożonej, 11.10.189o. 
dołączyła do misji w $1893 \mathrm{roku}^{47}$. Dowodzi to nacisku, jaki kładli anglikanie na zachowanie - przynajmniej formalnie - tradycji i zwyczajów lokalnych chrześcijan.

Praca prowadzona przez siostry w Persji w ramach misji arcybiskupa wiązała się z koniecznością pozyskania środków finansowych. W 1893 roku arcybiskup Benson pisał w liście do s. Katherine o trudnościach finansowych, podkreślając, że wydatki w roku 1892 przekroczyły wpływy ${ }^{48}$. Z zestawienia przygotowanego przez s. Ellen Joannę wynika, że od 189 o roku wydatki wzrastały systematycznie i wynosily w latach: 1890 - 231 funtów; 1891 - 280 funtów; 1892 - 357 funtów; $1893-375$ funtów; $1894-356$ funtów $^{49}$. Niewielkie koszty w pierwszym roku wynikały z rozpoczęcia zajęć lekcyjnych dopiero we wrześniu. W kolejnych latach przybywało uczniów pochodzących z biednych obszarów górskich. Ich pobyt $\mathrm{w}$ szkole wiązał się z koniecznością pokrycia wydatków na jedzenie. Roczna szacunkowa kwota utrzymania ucznia wynosiła 4-5 funtów ${ }^{50}$. Dodatkowo stosunkowo duży koszt stanowily tekstylia sprowadzane z Wielkiej Brytanii na ubrania oraz kołdry dla dzieci, a także fundusze na adaptację sal, w których prowadzono zajęcia, nie licząc innych wydatków pośrednio związanych z działalnością sióstr, jak druk książek czy materiałów szkolnych. Ważną część środków pochłaniał specjalny „fundusz na wypadek głodu”. Ogólnie jednak misja anglikańska nie należała do bogatych, czym można tłumaczyć niewielką liczbę sióstr pracujących w Urmii. Zdecydowanie zamożniejsza była misja amerykańska ${ }^{51}$. Stąd być może w ostatnich listach przed opuszczeniem Urmii s. Pauline ze smutkiem przyznała: „Koniec wydaje się być bardzo bliski. Smutno patrzeć, jak rozwija się misja amerykańska, a nasza musi być przerwana, wkrótce nie będzie tu już nikogo prócz prezbiterian"52. Niewątpliwie rezygnacja z pracy sióstr miała również związek ze śmiercią arcybiskupa Bensona. Nowy arcybiskup Frederick Temple (1896-1902) nie był już tak zdeterminowany, by rozwijać działalność wśród Asyryjczyków.

47 Zob. ssba, List s. Anne Pauline do matki przełożonej, 22.10.1893.

${ }^{48}$ Zob. ssBa, List arcybiskupa Bensona do s. Katherine Milldred, 30.08.1893.

49 Zob. ssBA, List s. Ellen Joanny do matki przełożonej, 5.01.1896.

50 Naukę wyznaczały niewątpliwie kalendarze obrzędowe i prace polowe, dotyczyło to zwłaszcza szkół wiejskich otwartych przez cztery miesiące w zimie, gdy dzieci nie były zajęte pracami (od końca listopada do połowy albo końca marca). Zob. W. H. Browne, A. J. Maclean, The Catholicos of the East..., dz. cyt., s. 162.

${ }_{51}$ Przed wysłaniem sióstr, w roku 1887 wpływy na prowadzenie misji arcybiskupa wynosiły 1300£, zaś misji amerykańskiej 550o£. Por. R. Waterfield, Christians in Persia..., dz. cyt., s. 129.

${ }^{52}$ ssBA, List s. Anne Pauline do matki przełożonej, 17.04.1898. 


\section{Znaczenie działalności sióstr w Persji: podsumowanie}

Działalność sióstr w Persji należy traktować jako przykład zróżnicowanych inicjatyw misyjnych podejmowanych przez Kościół Anglii w XIX wieku, prowadzących do zintensyfikowania kontaktów z Kościołami chrześcijańskimi oraz przedstawicielami innych religii. Misje określają i wyznaczają sposób kategoryzowania odmiennych kultur oraz społeczności, pociągając za sobą konieczność dokonania autorefleksji będącej początkiem naukowego dyskursu.

Siostry, opisując wjazd do Urmii w maju 1890 roku, wspominały rzesze witających je ludzi, wśród których byli pracownicy misji, katoliccy księża, chrześcijanie, muzułmanie ${ }^{53}$. Informacja ta jest istotna ze względu na ukazanie relacyjnego i (auto)refleksyjnego charakteru działań misyjnych. Faktycznie problem kontaktów między misjonarzami różnych wyznań, relacje z zarządcami miast, ludnością chrześcijańską i muzułmańską jest stosunkowo dobrze udokumentowany w listach i raportach. Wyeksponowany zostaje problem kontaktów z Persami oraz Kurdami. Relacje z Persami miały głównie charakter oficjalny, oni wszak byli zarządcami prowincji, wsi, czy w końcu reprezentantami szacha w tym regionie. Siostry przekazywały stosunkowo dużo informacji o świętach muzułmańskich - szyickich, zwłaszcza o obrzędach związanych $\mathrm{z}$ upamiętnieniem śmierci szyickiego imama Husajna w bitwie pod Karbalą z 680 roku obchodzonym 10 dnia miesiąca muharram. Relacje mają niewątpliwie wartość poznawczą, oferując niemalże etnograficzny opis niewielkich chrześcijańskich i muzułmańskich społeczności. Są one dodatkowo wzmocnione materiałem ilustracyjnym - rysunkami sióstr oraz fotografiami.

W przypadku Asyryjczyków działalność misyjna wiązała się z wprowadzeniem ujednoliconego i nowoczesnego systemu nauczania, któremu towarzyszyły egzaminy po każdym roku nauki. W egzaminach uczestniczyli pracownicy konsulatów brytyjskich w Persji. O skali edukacyjnego i egzaminacyjnego przedsięwzięcia świadczy fakt, że przeprowadzono egzaminy w ponad 6o szkołach wiejskich w całym regionie ${ }^{54}$. Trudno oszacować, jaki był rzeczywisty wpływ działalności sióstr na kobiety asyryjskie. Wyjątkiem może być rodzina patriarchy, z którą anglikanie utrzymywali bardzo dobre kontakty. Po śmierci brata patriarchy Szamaszy Eszai w 1895 roku siostry zajęły się jego córką Surmą. W tradycji Asyryjskiego Kościoła Wschodu patriarchat był instytucją dziedziczną, toteż następcą Mar Szimuna XVıII Rubena miał zostać syn jego

${ }_{53}$ Zob. ssbA, List s. Ellen Joanny do matki przełożonej, 16.05.189o.

54 Zob. „Archbishop's Mission to the Assyrian Christians Quarterly Paper” Report 1894, s. 33. 
brata Eszai. W 1902 roku faktycznie został nim Benjamin - Mar Szimun XIX, brat Surmy. Surma, utrzymująca kontakt z siostrami również po zakończeniu ich misji w Urmii, w trudnym dla Asyryjczyków okresie po pierwszej wojnie światowej i po śmierci brata, wspomnianego wyżej patriarchy Mar Szimuna XIX Benjamina w 1918 roku, odgrywała istotną rolę polityczną ${ }^{55}$.

Działalność sióstr z anglikańskiego zgromadzenia ssB w Persji w latach 1890-1898 można rozpatrywać z trzech perspektyw: 1) historii misji chrześcijańskich w Xıx wieku, zwłaszcza brytyjskich, które przeszczepiają europejską nowoczesność na tereny misyjne w postaci szkół, szpitali, drukarni. W transferze owej nowoczesności siostry odegrały istotną rolę; 2) historii Kościoła Anglii. Pojawienie się zgromadzeń zakonnych w obrębie anglikanizmu w XIX wieku ukazuje zmiany w nim zachodzące. Dodatkowo aktywność zgromadzeń żeńskich dowodzi przedefiniowania roli kobiet w społeczeństwie wiktoriańskim; 3) historii Asyryjskiego Kościoła Wschodu. Znaczenie działalności sióstr zasadza się zarówno na dokumentacji życia codziennego członków Kościoła, zwłaszcza kobiet, jak i na bezpośrednim oddziaływaniu na elity. Dotyczy to przede wszystkim rodu patriarchy, zwłaszcza zaś Surmy D’Bait Mar Szimun.

\section{ABSTRAKT}

Działalność sióstr należących do Society of the Sisters of Bethany w Persji wśród Asyryjczyków w latach 1890-1898 stanowiła część szerszego przedsięwzięcia misyjnego realizowanego pod auspicjami arcybiskupa Canterbury - The Archbishop of Canterbury's Mission to the Assyrian Christians. Celem misji było wsparcie Asyryjskiego Kościoła Wschodu poprzez promocję edukacji oraz druk ksiąg liturgicznych. Artykuł, przedstawiając okoliczności wysłania sióstr, skupia się na wymiarze edukacyjnym prowadzonej przez nie działalności, ukazuje przy tym odmienność i unikatowość prowadzonych działań na tle prezbiteriańskich i katolickich inicjatyw misyjnych podejmowanych wśród ludności asyryjskiej w tym czasie.

\section{SEOWA KLUCzowe}

Kościół Anglii, Sisters of Bethany, Asyryjski Kościół Wschodu, misje, Persja

${ }_{55}$ Zob. C. Weibel Yacoub, Surma l'Assyro-Chaldéenne (1883-1975). Dans la tourmente de Mésopotamie, Paris 2007, s. 118-122. 


\section{Abstract \\ The Activity of the Anglican Sisters of Bethany in Persia during the years 1890-1898 in the Context of Relations between the Church of England and the Assyrian Church of the East}

The activity of the Anglican sisters from the Society of the Sisters of Bethany among the Assyrians in Persia during the years 1890-1898 was a part of the broader missionary project undertaken by the Archbishop of Canterbury - The Archbishop of Canterbury's Mission to the Assyrian Christians. The purpose of the mission was to support the Assyrian Church of the East by developing educational system and printing liturgical books. The article presenting the circumstances under which the sisters were sent to mission is focused on educational aspect of their work, it portrays the differences and uniqueness of their activity comparing it with missionary initiatives undertaken by the Presbyterians and Roman Catholics among the Assyrian people at that time.

\section{KEYWORDS}

Church of England, Sisters of Bethany, Assyrian Church of the East, missions, Persia

\section{BibliografiA}

\section{I. Źródła}

\section{A. Źródła rękopiśmienne}

The National Archives [TNA], Foreign Office Records [Fo] Londyn FO 78/2698 - Persia: Nestorian Christians 1840-1844

FO 78/2700 - Persia: Nestorian Christians 1853-1864 FO 78/2702 - Persia: Nestorian Christians 1867-1877

Lambet Palace Library [LPL], archiwa arcybiskupa Canterbury, Londyn Assyrian Mission Papers G 32003

Society of the Sisters of Bethany, archiwum zakonne [ssB A], Portsmouth List Bensona do Etheldredy Anny, 14.05.1889.

List Macleana do Etheldredy Anny, 12.09.1889.

List s. Ellen Joanny do matki przełożonej, 16.05.189o.

List s. Ellen Joanny do matki przełożonej, 11.10.189o.

List s. Anne Pauline do matki przełożonej, 22.10.1893.

List arcybiskupa Bensona do s. Katherine Milldred, 30.08.1893.

List s. Ellen Joanny do matki przełożonej, 5.01.1896. 
List s. Anne Pauline do matki przełożonej, 17.04.1898.

List s. Anne Pauline do matki przełożonej, 8.05.1898.

The Persian Adventure 1890-1898, rkps.

\section{B. Źródła drukowane}

Badger G. P., The Nestorians and their Rituals, vol. 1-2, London 1852.

Bird I., Journey in Persia and Kurdistan Including a Summer in the Ipper Karun Region and $a$ Visit to the Nestorian Rayahs, vol. 2, London 1891.

Browne W. H., Maclean A. J., The Catholicos of the East and His People being the Impression of Five Years' Work in the "Archbishop of Canterbury's Assyrian Mission”. An Account of the Religious and Secular Life and Opinions of the Eastern Syrian Christians of Kurdistan and Northern Persia, London 1892.

Cutts E. L., The Assyrian Christians. Report of a Journey, Undertaken by Desire of His Grace the Archbishop of Canterbury and His Grace the Archbishop of York to the Christians in Koordistan and Oroomiah, London 1877.

Cutts E. L., Christians under the Crecsent in Asia, London 1878.

Cutts E. L., Amina: A Tale of the Nestorians, London [189o].

Dwight H. G., Smith E., Researches in Armenia Including a Journey through Asia Minor and into Georgia and Persia, vol. 1-2, Boston 1833.

Heazell F. N., Margoliouth J. P., Kurds and Christians, London 1913.

Jervis A. S., Diary in Persia with Memoir, Worthing 1893.

Perkins J., A Residence of Eight Years in Persia, among the Nestorian Christians: with Notices of the Muhammedans, Andover-New York 1843.

\section{Opracowania}

Becker A. H., Revival and Awakening. American Evangelical Missionaries in Iran and the Origin of Assyrian Nationalism, Chicago-London 2015.

Baumer C., The Church of the East. An Illustrated History of Assyrian Christianity, London 2016.

Coakley J. F, The Church of the East and the Church of England: A history of the Archbishop of Canterbury's Assyrian Mission, Oxford 1992.

Coakley J. F., Assyrian Christians in English Fiction, 1849-1967, „Journal of Assyrian Academic Studies" 23 (2009) no. 2, s. 18-25.

Francis-Dehqani G. E., Religious Feminism in an Age of Empire. CMs Women Missionaries in Iran 1869-1934, Bristol 2000.

Guest J. S., The Euphrates Expedition, London 1992.

Mumm S., Stolen Daughters, Virgin Mothers: Anglican Sisterhoods in Victorian Britain, London 1999. 
Murre-van den Berg H. L., From a Spoken to a Written Language. The Introduction and Development of Literary Urmia Aramaic in the Nineteenth Century, Leiden 1999. Waterfield R., Christians in Persia. Assyrians, Armenians, Roman Catholics and Protestants, London 1973.

Weibel Yacoub C., Surma l'Assyro-Chaldéenne (1883-1975). Dans la tourmente de Mésopotamie, Paris 2007.

Wimshurst D., The Martyred Church. A History of the Church of the East, London 2011.

III. Czasopisma, druki ulotne

"Letters from Assyria”

"Archbishop's Mission to the Assyrian Christians. Quarterly Paper" 1890 no. 1; 1891 no. 5, 1892 no. 7; 1892 no. 8; Report 1894. 